\title{
IMPLEMENTING BIOSAFETY PROCEDURES IN DEVELOPING COUNTRIES: ACCESSING INDEPENDENT, IMPARTIAL ADVICE
}

\author{
R.J. FREDERICK \\ Biotechnology Advisory Commission \\ Stockbolm Environment Institute \\ P.O. Box 2142, 10314 Stockholm, Sweden
}

\begin{abstract}
International efforts to incorporate biotechnology in national development schemes have prompted great interest in the formulation of biosafety regulations and guidelines. Adoption of the regulatory instruments is, however, only the first step in the process of ensuring the safe application of these technologies. Implementing guidelines can be done most efficiently and effectively when the experience and expertise of knowledgeable scientists are accessible. Through the organisation of the Biotechnology Advisory Commission, an impartial advisory service for biosafety implementation is offered to developing countries.
\end{abstract}

Key Words: Biosafety, Biotechnology Advisory Commission

\section{RÉSUMÉ}

Des efforts internationaux pour introduire la biotechnologie aux plans nationaux de développement ont incité un grand intérêt dans la formulation de règlements et directives sur la biosécurité. L'adoption des instruments régulateurs n'est, toutefois, que le premier pas dans le processus d'assurer l'application sans risque de ces technologies. L'exécution de directives peut être achevée plus efficacement quand l'expérience et la compétence de scientifiques bien informés sont accessibles. Par l'organisation de la Commission Consultative sur les Biotechnologies, un service consultatif impartial pour l'application de la biosécurité est offert aux pays en voie de développement.

Mots Clés: Biosécurité, Commission Consultative sur les Biotechnologies

\section{INTRODUCTION}

To a growing majority of the world's population, environmental hostility is a way of life. The daily battle against the elements of nature to provide food and shelter voraciously consumes individuals' time and energy. It condemns human beings to survival strategies which, though good enough to confirm the adaptive genius of the human species, do not provide much opportunity for the enhancement of human dignity and a creative exploration of the non-instinctive aspects of the human potential (Okoth-Okembo, 1994). As national leaders consider ways to ameliorate the impacts of environmental hostility on their citizenry, the lure of integrating innovative technologies into national development schemes is a recurrent theme.

For nearly 20 years, international attention has focused on a group of technologies which, when 
combined, fall into a category commonly called modern biotechnology. This is particularly evident in documents such as the Convention on Biological Diversity (Krattiger and Lesser, 1994). Called the wave of the future, biotechnology is a powerful and exciting field of science with sweeping implications for all biological research and development, and perhaps most importantly to developing countries, especially in agricultural and environmental applications. Recognising biotechnology as an important opportunity for science-based industrialisation, organisations such as the newly formed African Foundation for Research and Development have chosen it as a priority area. It will be necessary to link "a production oriented $R \& D$ programme to the development of a pilot biotechnology industrial park, with specialties in areas such as food processing, seeds, primary and veterinary healthcare, and microbiology-based applications like pesticides, environmental management technologies, and energy" (Odhiambo, 1994).

The road from stimulating possibilities to functioning technology is, however, a long and complicated one. It necessarily involves adiversity of public and private sectors, e.g., national and industrial research institutes, governmental ministries, universities, non governmental organisations (NGOs), commercially-oriented input companies, product associations, commodity institutes and consultancy and management companies (Brenner and Komen, 1994; Virgin and Frederick, 1995). Among the many issues that must be dealt with are priority setting, building technical capacity, transferring technology, and ensuring safety. Within the context of biotechnology, ensuring safety is commonly referred to as biosafety. Defined as "the policies and procedures adopted to ensure the environmentally safe applications of biotechnology" (Persley et al., 1992), it is viewed as an essential component of the process in order to protect the environment and biodiversity, to foster public acceptance, and to facilitate access to the technologies (Komen and Persley, 1993; Krattiger and Rosemarin, 1994).

\section{ADOPTION OF BIOSAFETY REGULATIONS}

Between 1987 and 1995, thirty-six countries adopted some sort of biosafety regulation(s) or guideline(s) (Virgin and Frederick, 1995). This is $23 \%$ of the 154 signatories to the Convention on Biological Diversity, with only nine in the lowermiddle to low income category. Even taking into consideration those countries that are actively drafting rules and regulations, estimates are that only $17 \%$ of the developing countries will have regulations in place by the end of 1996 unless some assistance is afforded. The need for information exchange, access to experience and impartial advice can not be overstated. International organisations such as ABSP, United Nations Industrial Development Organisation (UNIDO), Organisation for Economic Cooperation \& Development (OECD), InterAmerican Institute for Cooperation on Agriculture (IICA), International Service for the Acquisition of Agri-biotech Applications (ISAAA), International Service for National Agricultural Research (ISNAR), and the Biotechnology Advisory Commission (BAC) are trying to satisfy that need with publications, workshops and training programmes.

\section{REGULATORY IMPLEMENTATION: THE NEXT STEP}

Preparing and institutionalising documents is a first step to ensuring biosafety. While prudence suggests that all reasonable consequences be considered, it is only through the process of environmental assessments that details can be appropriately considered. Consequently, if harmonisation guidance is to be most effective, we must consider how biosafety guidelines will be applied and used not only by those who are responsible for evaluating the biosafety of projects and products, but also those who are required to have approval before conducting field tests or selling their products. The experience of others who have implemented guidelines or regulations 
can be a valuable resource. The recently formed BAC has been established to provide direct assistance to developing and poor countries concerned about the safe application of biotechnology in agriculture and the environmental industry.

\section{FORMATION OF A BIOTECHNOLOGY ADVISORY COMMISSION}

In December of 1990 in Sigtuna, Sweden, a biosafety workshop was held. At this workshop the participants considered a proposal for an independent international biosafety panel. Members of the panel would be international experts acting in their individual capacity to provide impartial advice on biosafety issues. Participants agreed that the idea had merit and an advisory panel for agricultural biotechnology should be created. Significantly, developing nation participants argued strongly for access to impartial advice on the scientific appropriateness of biotechnology approaches to their particular national goals and on steps that should be taken when evaluating proposals.

The Stockholm Environment Institute agreed to provide a base for the formation of such a commission. In the ensuing three years, financial support was found through grants from Swedish donor agencies, from the Rockefeller Foundation and from internal institute resources. Fifteen internationally recognised scientists and legal experts volunteered to constitute the advisory body. These members have a wide range of experience in scientific and other disciplines including applied ecology, ecological genetics, microbial ecology, molecular biology of plants

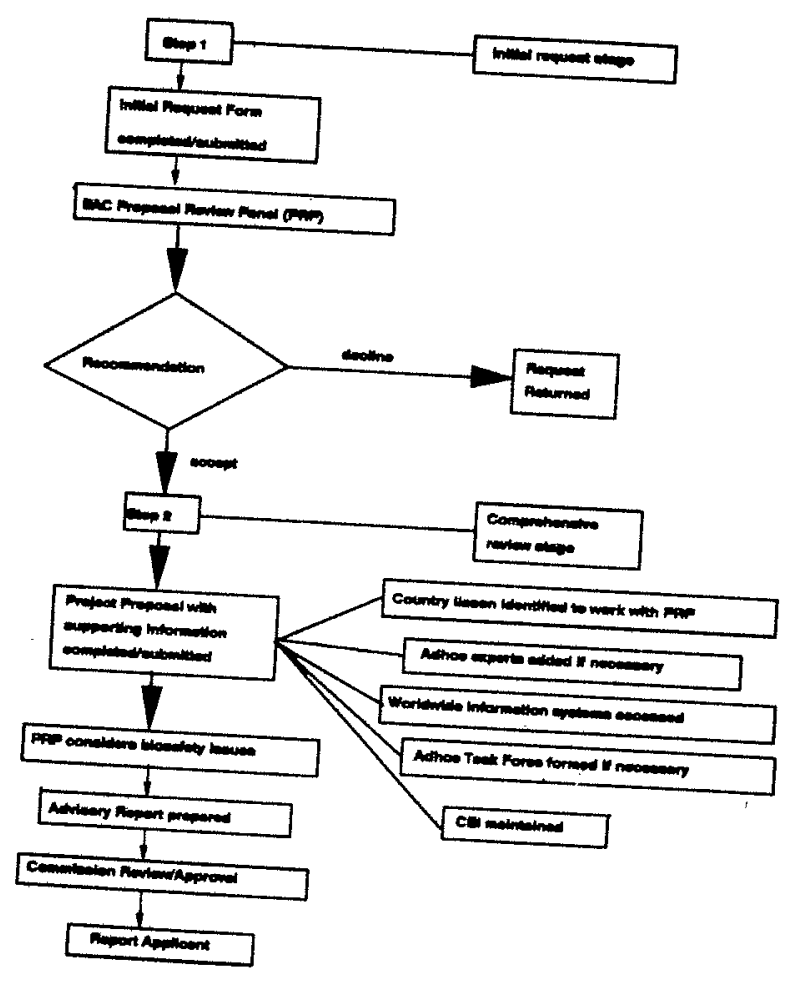

Figure 1. Two step flow diagram for receiving advice from the Biotechnology Advisory Commission 
and micro-organisms, entomology, genetics, marine biotechnology, and plant pathology, as well as international environmental and regulatory law and economics. Equally important is that all of these members have considerable experience in the development and implementation of biosafety guidelines and regulations.

\section{A SIMPLE, TWO-STEP REVIEW PROCESS}

The BAC has established procedures that it will use to provide assistance. In response to specific requests, for example how to assess the biosafety of a proposed field test using a genetically modified organism, the BAC will, through a two step process, provide its impartial advice. The first step (Fig. 1) involves the completion of an Initial Request Form with summary information about the field test and specific questions to be addressed by the BAC. A Proposal Review Panel (PRP) constituted by BAC members will evaluate the request and make a recommendation whether to decline or accept the request. Reasons for declining the request might be because the scope of the proposal is outside the purview of the BAC (e.g., human use protocols) ordoes not relate to biosafety issues.

If the initial request is accepted, a complete project proposal with supporting material will be asked for so that a more comprehensive review can be done. In this second step, the PRP may be supplemented with outside experts on an ad hoc basis. A country liaison will be identified and invited to participate as an observer. If needed, an ad hoc task force may be commissioned at BAC expense to collect additional information (e.g., through a site visit). Throughout the process, the BAC will be sensitive to, and maintain the confidentiality of, business information. After an advisory report has been prepared, the BAC will review the findings and make a report to the applicant.

Since the BAC is being supported by the Stockholm Environment Institute and outside funding agencies, it will be possible to maintain a completely impartial view in these evaluations. It is intended that any advice given will be in a form that is useful to regulatory authorities in their decision making process. It is important to note, however, that no decision recommendations will be offered. In fact, as an independent, impartial body, the BAC is not in the position to make those kinds of determinations.

\section{OTHER AREAS OF ASSISTANCE}

In January of 1995, the BAC in cooperation with the International Institute of Tropical Agriculture conducted a workshop on implementation of biosafety guidelines for Nigeria. Representatives of national ministries, universities and research institutions learned about biosafety assessment practices and how they are currently being used in other countries. Such workshops are intended to help bridge the gap between theory and practice in a setting apart trom the requirements for a regulatory decision.

The BAC is actively offering assistance through other supplementary activities. The construction of a variety of information data bases and electronic data resources, for example by UNIDO, OECD, United States Department of Agriculture (USDA), and $\mathrm{CAB}$ International, are now available, but while access is quite easy in the industrialised countries, there are perhaps difficulties in using such systems efficiently elsewhere. We anticipate that the BAC headquarters may act as an intermediary to obtain such information. Already, hard copies of regulatory instruments and background materials have been provided in response to specific requests.

\section{CONCLUSIONS}

With the overwhelming majority of developing countries still in the process of determining their role in agricultural and environmental biotechnology, there will be an increasing demand for access to experience and expertise. Whatever mechanisms are employed, it is generally agreed that biosafety will be a critical component in the efficient and effective transfer of this technology to developing countries. International organisations will play a key role in this process for the foreseeable future. 


\section{REFERENCES}

Brenner, C. and Komen, J. 1994. International initiatives in biotechnology for developing country agriculture: Promises and Problems. OECD Development Centre Technical Paper No. 100 . 60 pp. Organisation for Economic Co-operation and Development, Paris.

Komen, J. and Persley, G.J. 1993. Agricultural Biotechnology in Developing Countries: A Cross-Country Review. ISNAR Research Report No.2. The Hague: International Service for National Agricultural Research.

Krattiger, A.F. and Lesser, W.H. 1994. Biosafety, an environmental impact assessment tool and the role of the Convention on Biological Diversity. In: Widening Perspectives on Biodiversity. Krattiger, A.F., McNeely, J.A., Lesser, W.H., Miller, K.R., St. Hill,Y. and Senanayake, R. (Eds.), pp. 353-366. IUCN, Gland, Switzerland, and International Academy of the Environment, Geneva, Switzerland.

Krattiger, A.F. and Rosemarin, A. 1994. Biosafety for Sustainable Agriculture: Sharing Biotechnology Regulatory Experiences of the Western Hemisphere. International Service for the Acquisition of Agri-biotech Applications (ISAAA): Ithaca and Stockholm Environment Institute (SEI): Stockholm, $278 \mathrm{pp}$.

Odhiambo, T.R. 1994. Biotechnology: Africa's beachhead for entry into the global economy. Bio/Technology 12:1400.

Okoth-Okembo, D. 1994. Forward. In: Masters of Survival. Odegi-Awuondo, C., Nami, H.W. and Mutsotso, B.M. (Eds.). Basic Books (Kenya) Limited. Nairobi, Kenya.

Persley, G.J., Giddings, L.V. and Juma, C. 1992. Biosafety: The Safe Application of Biotechnology in Agriculture and the Environment. The Hague: International Service for National Agricultural Research.

Virgin, I. and Frederick, R. 1995. The impact of international harmonisation on adoption of biosafety regulations. African Crop Science Journal 3:387-394. 
$*$ 